\title{
DIDACTICS: METHODOLOGICAL APPROACHES TO DETERMINING THE CONTENT OF PHYSICAL EDUCATION TEACHER TRAINING
}

\author{
Olha, Ivashchenko ${ }^{1 \mathrm{ABCD}}$, Radosław Muszkieta ${ }^{2 \mathrm{ABCD}}$,Vladimir Potop ${ }^{3 \mathrm{ABCD}}$ \\ ${ }^{1}$ H. S. Skovoroda Kharkiv National Pedagogical University \\ ${ }^{2}$ Nicolaus Copernicus University in Toruń \\ ${ }^{3}$ Ecological University of Bucharest \\ Authors' Contribution: A - Study design; B - Data collection; C - Statistical analysis; D - Manuscript Preparation; E - Funds Collection
}

DOI: $10.17309 / \mathrm{jltm} .2020 .1 .06$

\begin{abstract}
The objective of the study was to develop methodological approaches to determining the content of physical education teacher training.

Materials and methods. The study involved 62 students of the School of Physical Education, who studied according to the 2001-2005 curriculum. To solve the tasks set, the study used both philosophical and general scientific research methods, including: dialectical method (principle of historicism, principle of systematicity, principle of dialectical contradiction, principle of unity of quality and quantity, principle of dialectical negation, principle of development, principle of causality); systems approach; factor and discriminant analysis.

Results. The results of performance analysis show an average level of proficiency in learning material. By the coefficient of variation, the grades in History of Modern World, Culturology, Gymnastics, TMPE, 3rd year vary considerably (>33\%). The students' performance in Therapeutic Physical Training, Fundamentals of Ecology, Thesis has an average level of variability. By most indicators, the students are assessed as a homogeneous group. The analysis of similarities (h2) showed that the most informative indicators of the quality of students' training are the grades in the following subjects: Teaching Practice (middle school) (0.817); Biomechanics (0.772); Qualification Examination (0.764); Teaching Practice (senior school) (0.763).

Conclusions. Factor and discriminant analysis provided objective information on the quality of physical education teacher training. The results of factor analysis do not confirm the objectivity of empirical identification of four groups of academic subjects of the curriculum.

The factor structure of the curriculum indicates the need to change the content of education, aimed at improving the training of highly qualified teachers. The training of a physical education teacher should include the following blocks of subjects: professional theoretical and practical training, natural sciences, theory and methods of physical education of schoolchildren, special training in the chosen sport. The results of discriminant analysis show that physical education teacher training is aimed at developing knowledge, abilities and skills in the sections: 1) Means and Methods of Physical Education; 2) Theory and Methods of Motor Abilities Development; 3) Theory and Methods of Teaching Motor Actions.
\end{abstract}

Keywords: physical education teacher, content of training, factor analysis, discriminant analysis.

\section{Introduction}

A characteristic feature of the improvement of physical education in Ukraine is constant expansion of curricula and programs, introduction of new subjects, increase in the number of hours for humanitarian and socio-economic training. The adaptation of the field to European standards has created a situation where students of different years of study are taught according to different curricula, which are continually edited.

(C) Olha Ivashchenko, Radosław Muszkieta,Vladimir Potop, 2020.
The methodology of studying the content of higher education was discussed in the papers by Perez-Encinas Adriana and Rodriguez-Pomeda Jesus (2018),Vukasovic Martina (2019), Liu Xiqian, and Borden Victor (2019). The prospects for the development of higher education from the standpoint of globalization and differentiation in higher education systems of different countries were studied by van Vught Frans A., van der Wende Marijk C., and Westerheijden Don F. (2018).

Modern research has considered the problem of professional training of physical education teachers (Muszkieta, 
Napierała, Cieślicka, Zukow, Kozina, Iermakov, \& Górny, 2019a; Muszkieta, Napierała, Zukow, Cieślicka, Iermakov, \& Kozina, 2019b), formation of competencies and motivation (Popovych, Zavatskyi, Tsiuniak, Nosov, Zinchenko, Mateichuk, Zavatskyi, \& Blynova, 2020;Prystupa, Kryshtanovych, Danylevych, Lapychak, Kryshtanovych, Sikorskyi, Podolyak, \& Basarab, 2020;Richards\& Levesque-Bristol, 2014); psychophysiological readiness for professional work (Kokun, Imas, Vovkohon, Potop, Korobeynikov, G., Ko- robeynikova, L., Gorashchenco, \& Polevaya-Secaryanu, 2018; Koh, Ong, \& Camiré, 2016).

In the XX century, curricula in Ukraine were modernized through the introduction of state standards for a period specified by law. The standards established a single normative and substantive basis for training specialists (Kravchuk, 2006, 2008). The analysis of archival materials revealed the trends in curricula changes, the basis of which is the balance of time allotted for general, pedagogical, and special training. Allocating $60 \%$ of time

Table 1. The results of student performance for the period 2001-2005

\begin{tabular}{|c|c|c|c|c|c|c|}
\hline No. & Subjects & $\mathrm{X}$ & S & $\mathrm{V}$ & As & Ex \\
\hline \multicolumn{7}{|c|}{ Cycle of humanitarian and socio-economic training } \\
\hline 1 & History of Modern World & 6.768 & 2.359 & 34,86 & 0.048 & -0.763 \\
\hline 2 & History of Ukraine & 7.087 & 2.201 & 31,06 & 0.024 & -1.062 \\
\hline 3 & Political Science & 7.899 & 1.467 & 18,57 & 0.176 & -1.127 \\
\hline 4 & Sociology & 7.290 & 1.767 & 24,24 & 0.004 & 0.962 \\
\hline 5 & Culturology & 6.087 & 2.195 & 36,06 & 0.072 & -0.710 \\
\hline 6 & Philosophy & 7.681 & 1.649 & 21,47 & 0.069 & -0.357 \\
\hline 7 & Fundamentals of Economics & 6.899 & 2.059 & 29,84 & -0.005 & -1.051 \\
\hline 8 & Fundamentals of Law & 9.116 & 2.019 & 22,15 & -0.071 & -0.460 \\
\hline 9 & Business Ukrainian Language & 8.087 & 1.861 & 23,01 & -0.119 & -0.354 \\
\hline 10 & Foreign Language & 7.246 & 1.826 & 25,2 & 0.090 & -0.614 \\
\hline \multicolumn{7}{|c|}{ Cycle of natural sciences training } \\
\hline 11 & Anatomy & 8.043 & 1.702 & 21,16 & -0.003 & -1.135 \\
\hline 12 & Anatomy & 7.348 & 1.969 & 26,8 & 0.046 & -0.951 \\
\hline 13 & Biochemistry & 6.406 & 2.002 & 31,25 & 0.084 & -0.330 \\
\hline 14 & Biomechanics & 7.174 & 2.155 & 30,04 & 0.034 & -1.061 \\
\hline 15 & Fundamentals of Ecology & 10.014 & 1.500 & 14,98 & -0.454 & 2.250 \\
\hline 16 & Hygiene & 7.377 & 1.699 & 23,03 & -0.012 & -0.600 \\
\hline 17 & General Physiology & 7.377 & 1.750 & 23,72 & 0.008 & -0.834 \\
\hline 18 & Sports Physiology & 7.609 & 1.873 & 24,62 & -0.021 & -1.115 \\
\hline 19 & Therapeutic Physical Training & 8.652 & 1.464 & 16,92 & 0.008 & -1.068 \\
\hline \multicolumn{7}{|c|}{ Cycle of psychological and pedagogical training } \\
\hline 20 & History of Pedagogy & 7.217 & 1.909 & 26,45 & 0.044 & -1.019 \\
\hline 21 & General Pedagogy & 8.072 & 1.897 & 23,5 & -0.016 & -0.801 \\
\hline 22 & Course Paper in Pedagogy & 7.913 & 1.788 & 22,6 & 0.001 & -0.839 \\
\hline 23 & General Psychology & 8.072 & 2.089 & 25,88 & -0.040 & -1.040 \\
\hline 24 & Age and Pedagogical Psychology & 7.217 & 1.635 & 22,65 & 0.041 & -0.660 \\
\hline 25 & Social Pedagogy & 7.536 & 2.076 & 27,55 & 0.029 & -1.056 \\
\hline 26 & Course Paper in Social Pedagogy & 8.072 & 1.897 & 23,5 & 0.012 & -1.134 \\
\hline \multicolumn{7}{|c|}{ Cycle of professional training } \\
\hline 27 & Sports and Pedagogical Improvement, 2nd year & 8.884 & 1.558 & 17,54 & 0.033 & -0.905 \\
\hline 28 & TMPE, 2nd year & 7.246 & 1.826 & 25,2 & 0.019 & -0.786 \\
\hline 29 & Swimming & 7.377 & 1.476 & 20,01 & 0.209 & -0.866 \\
\hline 30 & Skiing & 8.290 & 1.486 & 17,93 & -0.090 & -0.766 \\
\hline 31 & Track-and-Field Athletics & 8.580 & 1.547 & 18,03 & -0.012 & -1.234 \\
\hline 32 & Gymnastics & 7.783 & 2.743 & 35,24 & 0.003 & -1.345 \\
\hline 33 & Sports Games & 8.348 & 1.670 & 20 & -0.015 & -0.114 \\
\hline 34 & TMPE, 3rd year & 7.536 & 2.564 & 34,02 & 0.012 & -1.248 \\
\hline 35 & Course Paper in TMPE & 7.435 & 1.989 & 26,75 & 0.014 & -0.876 \\
\hline 36 & Course Paper in Specialty & 9.522 & 1.357 & 14,25 & 0.010 & -0.634 \\
\hline 37 & Sports and Pedagogical Improvement, 4th year & 9.174 & 1.372 & 14,96 & -0.125 & -0.465 \\
\hline 38 & Teaching Practice (middle school) & 8.348 & 2.549 & 30,53 & -0.006 & -1.241 \\
\hline 39 & Teaching Practice in Children's Health Camps & 8.609 & 1.784 & 20,72 & -0.103 & -0.019 \\
\hline 40 & Teaching Practice (senior school) & 8.319 & 2.193 & 26,36 & -0.029 & -0.746 \\
\hline 41 & Qualification Examination & 8.319 & 1.761 & 21,17 & 0.057 & -0.945 \\
\hline 42 & Thesis & 9.101 & 1.742 & 19,14 & -0.030 & -0.625 \\
\hline
\end{tabular}


Table 2. The structure of professional training of a physical education teacher. Factor matrix after rotation (specified loads > $|0.30|(n=62)$

\begin{tabular}{|c|c|c|c|c|c|c|}
\hline \multirow{2}{*}{ No. } & \multirow{2}{*}{ Subjects } & \multicolumn{4}{|c|}{ Factors } & \multirow{2}{*}{$\mathbf{h}^{2}$} \\
\hline & & 1 & 2 & 3 & 4 & \\
\hline 1 & History of Modern World & & -0.579 & & & 0.451 \\
\hline 2 & History of Ukraine & & -0.813 & & & 0.763 \\
\hline 3 & Political Science & 0.507 & -0.334 & 0.370 & -0.473 & 0.729 \\
\hline 4 & Sociology & 0.473 & & 0.412 & & 0.547 \\
\hline 5 & Culturology & 0.353 & -0.532 & & & 0.528 \\
\hline 6 & Philosophy & 0.682 & & 0.335 & & 0.646 \\
\hline 7 & Fundamentals of Economics & & -0.343 & & & 0.281 \\
\hline 8 & Fundamentals of Law & & -0.326 & 0.604 & & 0.525 \\
\hline 9 & Business Ukrainian Language & & & 0.576 & & 0.526 \\
\hline 10 & Foreign Language & 0.435 & -0.488 & & -0.332 & 0.562 \\
\hline 11 & Anatomy & & -0.629 & 0.388 & -0.306 & 0.645 \\
\hline 12 & Anatomy & & -0.745 & & & 0.702 \\
\hline 13 & Biochemistry & 0.367 & -0.746 & & & 0.729 \\
\hline 14 & Biomechanics & 0.302 & -0.790 & & & 0.772 \\
\hline 15 & Fundamentals of Ecology & & & 0.470 & & 0.364 \\
\hline 16 & Hygiene & 0.524 & -0.408 & 0.453 & & 0.647 \\
\hline 17 & General Physiology & 0.461 & -0.505 & 0.306 & -0.396 & 0.718 \\
\hline 18 & Sports Physiology & 0.430 & & 0.582 & & 0.669 \\
\hline 19 & Therapeutic Physical Training & 0.638 & & & & 0.597 \\
\hline 20 & History of Pedagogy & & -0.711 & & & 0.588 \\
\hline 21 & General Pedagogy & 0.410 & & 0.302 & -0.503 & 0.567 \\
\hline 22 & Course Paper in Pedagogy & 0.451 & & 0.356 & -0.387 & 0.530 \\
\hline 23 & General Psychology & 0.587 & -0.368 & & & 0.569 \\
\hline 24 & Age and Pedagogical Psychology & 0.584 & -0.348 & 0.442 & & 0.712 \\
\hline 25 & Social Pedagogy & 0.622 & -0.360 & 0.376 & & 0.676 \\
\hline 26 & Course Paper in Social Pedagogy & 0.518 & & 0.450 & & 0.559 \\
\hline 27 & Sports and Pedagogical Improvement, 2nd year & & -0.442 & 0.433 & & 0.495 \\
\hline 28 & TMPE, 2nd year & 0.647 & & & -0.360 & 0.617 \\
\hline 29 & Swimming & 0.645 & & 0.343 & & 0.661 \\
\hline 30 & Skiing & & -0.300 & 0.597 & -0.355 & 0.654 \\
\hline 31 & Track-and-Field Athletics & 0.629 & & 0.301 & -0.393 & 0.683 \\
\hline 32 & Gymnastics & 0.571 & -0.348 & & -0.309 & 0.631 \\
\hline 33 & Sports Games & & -0.411 & & -0.665 & 0.734 \\
\hline 34 & TMPE, 3rd year & & & 0.760 & & 0.716 \\
\hline 35 & Course Paper in TMPE & & & 0.646 & & 0.554 \\
\hline 36 & Course Paper in Specialty & & & & -0.817 & 0.749 \\
\hline 37 & Sports and Pedagogical Improvement, 4 th year & & & & -0.744 & 0.718 \\
\hline 38 & Teaching Practice (middle school) & & & 0.851 & & 0.817 \\
\hline 39 & Teaching Practice in Children's Health Camps & 0.554 & & & & 0.406 \\
\hline 40 & Teaching Practice (senior school) & 0.696 & & & -0.444 & 0.763 \\
\hline 41 & Qualification Examination & 0.669 & -0.321 & 0.360 & & 0.764 \\
\hline \multirow[t]{2}{*}{42} & Thesis & & -0.305 & & -0.694 & 0.707 \\
\hline & $\%$ & 30.800 & 26.462 & 24.294 & 18.444 & 62.55 \\
\hline
\end{tabular}

for special training ensured quality training of specialists (Kravchuk, 2006). However, studies did not analyze the effectiveness of curricula by the level of students' knowledge, did not determine the curriculum structure based on multidimensional statistics.

The objective of the study was to develop methodological approaches to determining the content of physical education teacher training.

\section{Materials and methods}

\section{Study participants}

The study involved 62 students of the School of Physical Education, who studied according to the 2001-2005 curriculum. 


\section{Study organization}

To solve the tasks set, the study used both philosophical and general scientific research methods, including: dialectical method (principle of historicism, principle of systematicity, principle of dialectical contradiction, principle of unity of quality and quantity, principle of dialectical negation, principle of development, principle of causality); systems approach; factor and discriminant analysis. The analysis was carried out based on subjects with an exam as the form of knowledge control.

\section{Statistical analysis}

The study materials were processed using IBM SPSS 20 statistical analysis software. Factor analysis was performed. In the factor analysis, the study used the model of principal components with the rotation method: Varimax with Kaiser Normalization.

For each canonical discriminant function, the study calculated: eigenvalue, dispersion percentage, canonical correlation, Wilks' Lambda, Chi-square.

\section{Results}

The analysis of the curriculum for training specialists has shown that it is divided into four groups of subjects:

I. Cycle of humanitarian and socio-economic training (10 subjects).

II. Cycle of natural sciences training (9 subjects). subjects).

III. Cycle of psychological and pedagogical training (5

IV. Cycle of professional training (9 subjects).

Cycle I includes $30.3 \%$, Cycle II - 27.27\%, Cycle III $15.5 \%$, Cycle IV $-27.27 \%$ of the subjects. This ratio of basic subjects in the curriculum shows a decrease in the number of hours for special training compared to humanitarian and general pedagogical training.

The results of performance analysis are given in Table 1 and indicate an average level of proficiency in learning material. By the coefficient of variation, the grades in History of Modern World, Culturology, Gymnastics, TMPE, 3rd year vary considerably (>33\%). The students' performance in Therapeutic Physical Training, Fundamentals of Ecology, Thesis has an average level of variability. By most indicators, the students are assessed as a homogeneous group.

Factor analysis identified four factors, which explain the variation of total dispersion by $62.55 \%$ (Table 2 ).

The first factor explains the variation of total dispersion by $30.8 \%$. With the first factor, the highest correlation is in the performance of the following subjects: Teaching Practice (senior school) (0.696), Philosophy (0.682), Qualification Examination on TMPE (0.669), General Principles of Theory and Methods of Physical Education (0.647), Swimming (0.645). ), Therapeutic Physical Training (0.638), Track-andField Athletics (0.629).

The factor characterizes practical and theoretical competence of graduates. The factor is called the Cycle of Theory and Methods of Physical Education and Sports Subjects.

The second factor explains the variation of total dispersion by $26.462 \%$. With the factor, the highest correlation is in the performance of the following subjects: History of Ukraine
(-0.813), Biomechanics (-0.790), Biochemistry (-0.746), Anatomy (-0.745), History of Pedagogy (-0.711). The factor is interpreted as a cycle of natural sciences.

The third factor explains the variation of total dispersion by $24.294 \%$. With the factor, the highest correlation is in the performance of the following subjects: Teaching Practice (middle school) (0.851), Theory and Methods of Physical Education (0.760), Course Paper in TMPE (0.646). The factor is interpreted as Theory and Methods of Physical Education of Schoolchildren.

The fourth factor explains the variation of total dispersion by $18.444 \%$. With the factor, the highest correlation is in the performance of the following subjects: Course Paper in Specialty (-0.817), Sports and Pedagogical Improvement $(-0.744)$, Thesis $(-0.694)$. The factor is interpreted as special training in the chosen sport.

Thus, the results of factor analysis do not confirm the objectivity of empirical identification of four groups of academic subjects. The factor structure of the curriculum indicates the need to change the content of education, aimed at improving the training of highly qualified teachers.

The analysis of similarities $\left(\mathrm{h}^{2}\right)$ showed that the most informative indicators of the quality of students' training are the grades in the following subjects:

- $\quad$ Teaching Practice (middle school) (0.817);

- Biomechanics (0.772);

- Qualification Examination (0.764);

- Teaching Practice (senior school) (0.763).

Since in the first factor the grade in Qualification Examination on TMPE (0.669) and General Principles of Theory and Methods of Physical Education (0.647) had the greatest weight, the study performed a discriminant analysis of the results of modular control in General Principles of Theory and Methods of Physical Education (Tables 3-6). The obtained testing results show an average level of proficiency in learning material (Table 3).

Table 3. The results of modular control in General Principles of Theory and Methods of Physical Education (grade according to a 100-point scale)

\begin{tabular}{lllll}
\hline No. & Topic & Mean & S & N \\
\hline 1.1 & Introduction to TMPE & 77.02 & 15.21 & 62 \\
1.2 & PE as a Social Phenomenon & 67.34 & 21.13 & 62 \\
2.1 & Physical Exercises & 74.6 & 17.68 & 62 \\
2.2 & Technique of Physical Exercises & 75.4 & 14.43 & 62 \\
2.3 & Classification of Physical Exercises & 78.89 & 14.21 & 62 \\
2.4 & Exercise and rest & 77.42 & 21.19 & 62 \\
2.5 & Methods of Physical Education & 84.28 & 17.47 & 62 \\
3.1 & Biological, Psychological and & 74.06 & 17.47 & 62 \\
& Pedagogical Patterns of Motor Activity & & & \\
3.2 & Agility & 74.46 & 14.14 & 62 \\
3.3 & Movement Coordination & 80.78 & 16.08 & 62 \\
3.4 & Strength Abilities & 83.87 & 9.99 & 62 \\
3.5 & Motor Endurance & 81.58 & 14.56 & 62 \\
3.6 & Flexibility & 77.68 & 10.85 & 62 \\
4.1 & Theoretical Principles of Teaching & 81.45 & 17.16 & 62 \\
& Physical Exercises & & & \\
4.2 & Characteristics of Teaching Motor & 80.24 & 17.15 & 62 \\
& Actions & & & \\
4.3 & Techniques of Teaching Motor Actions & 76.74 & 11.98 & 62 \\
\hline
\end{tabular}


Table 4. Canonical discriminant function. Eigenvalues.

\begin{tabular}{lcccc}
\hline Function Eigenvalue & $\begin{array}{c}\text { \% of } \\
\text { Variance }\end{array}$ & $\begin{array}{c}\text { Cumulative } \\
\text { \% }\end{array}$ & $\begin{array}{c}\text { Canonical } \\
\text { Correlation }\end{array}$ \\
\hline 1 & 3351.623 & 71.1 & 71.1 & .980 \\
2 & 1358.421 & 28.8 & 99.9 & .980 \\
3 & 2.841 & .1 & 100.0 & .860 \\
\hline
\end{tabular}

Table 5. Canonical discriminant function. Wilks' Lambda

\begin{tabular}{lcccc}
\hline Test of Function(s) & Wilks' Lambda & Chi-square & df & Sig. \\
\hline 1 through 3 & .001 & 116.746 & 36 & .001 \\
2 through 3 & .001 & 59.924 & 22 & .001 \\
3 & .260 & 9.420 & 10 & .493 \\
\hline
\end{tabular}

Table 6. Functions at group centroids

\begin{tabular}{lrrr}
\hline \multirow{2}{*}{ Modules } & \multicolumn{3}{c}{ Function } \\
\cline { 2 - 4 } & $\mathbf{1}$ & $\mathbf{2}$ & $\mathbf{3}$ \\
\hline 1 & -110.235 & -30.238 & 1.644 \\
2 & 44.192 & 11.538 & 1.659 \\
3 & 18.432 & -27.385 & -1.302 \\
4 & -37.027 & 55.699 & -1.258 \\
\hline
\end{tabular}

The first canonical function explains the variation of results by $71.1 \%$, the second - by $28.8 \%$, which indicates a high informativeness of the first and second canonical functions $(r=0.98)$ (see Table 4). Table 5 shows the material of the analysis of canonical functions. The first line contains the value $\lambda_{1}=0.001$ and statistical significance $p=0.001$ for the whole set of canonical functions, the second line contains data after excluding the second function $\left(\lambda_{2}=0.001, \mathrm{p}=\right.$ 0.001 ). The first and second functions have a high discriminant ability and value in the interpretation of the general population.

The graphic material given in Fig. 1 shows a clear boundary between the level of knowledge of the four modules of the course. In the positive pole of the first function, there are average values of the level of knowledge (centroids) of the second and third modules, in the negative - average values of the level of knowledge (centroids) of the first and fourth modules (Table 6).

According to the analysis of the first function, the students have better knowledge of the modules "Means and Methods of Physical Education", "Theory and Methods of Motor Abilities Development"; according to the analysis of the second function, the module "Theory and Methods of Teaching Motor Actions" has the highest value.

\section{Discussion}

The paper assumed that the use of multidimensional statistics would provide an opportunity to obtain new information about the curriculum structure in the process of training a physical education teacher.

It was found that factor and discriminant analysis provides objective information on the quality of training a physical education teacher. The results of factor analysis do not confirm the objectivity of empirical identification of four groups of academic subjects. The factor structure of the curriculum indicates the need to change the content of education, aimed at improving the training of highly qualified teachers.

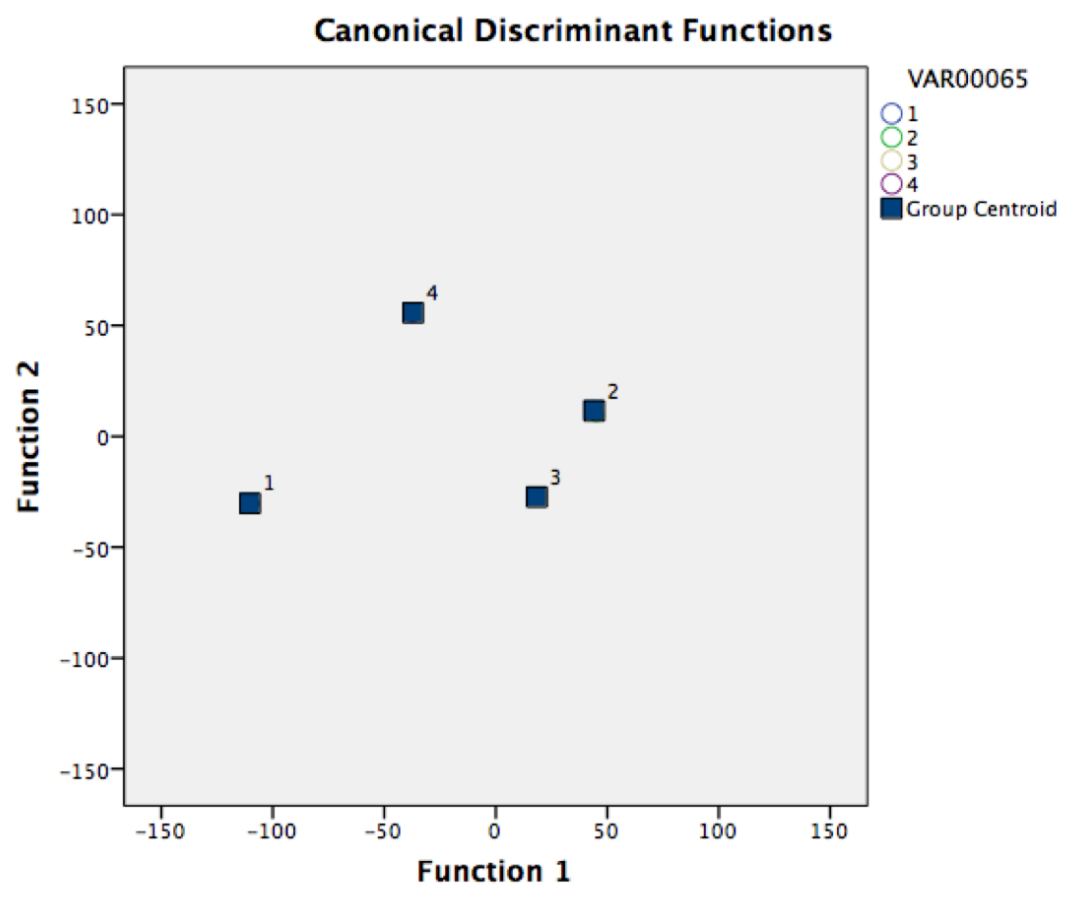

Fig. 1. Canonical discriminant functions. Graphic representation of the results of classification of knowledge assessment by four modules: 1 - "Physical Education in Education System", 2 - "Means and Methods of Physical Education", 3 - "Theory and Methods of Motor Abilities Development", 4 - "Theory and Methods of Teaching Motor Actions" 
The training of physical education teachers should include the following blocks of subjects: professional theoretical and practical training, natural sciences, theory and methods of physical education of schoolchildren, special training in the chosen sport.

The obtained results supplement the data of Kravchuk $(2006,2008)$ on the trends in curricula changes, the basis of which is the balance of time allotted for general, pedagogical, and special training.

The results of factor analysis confirm the opinion of Backman and Barker (2020) that the training of physical education teachers should include the development of: 1) knowledge of technique and tactics of physical exercises; 2) knowledge of programming the process of teaching physical exercises; 3) knowledge of quality assessment of the educational process. The level of competence of physical education teachers should be quantitative.

The results of discriminant analysis confirm the thematic integrity of the subject "General Principles of Theory and Methods of Physical Education" and supplement the data of Roters (2007), Serhiienko $(2009,2010)$ on planning the study of special subjects; those of Khudolii and Ivashchenko (2008, 2012), Ivashchenko and Khudolii (2010) on teaching the subject "Theory and Methods of Physical Education" in the process of training a physical education teacher; Khudolii and Zabora (2002) on the state and ways to improve the teaching of special subjects in the system of basic education at physical education schools of pedagogical educational institutions.

\section{Conclusions}

Factor and discriminant analysis provided objective information on the quality of physical education teacher training. The results of factor analysis do not confirm the objectivity of empirical identification of four groups of academic subjects of the curriculum. The factor structure of the curriculum indicates the need to change the content of education, aimed at improving the training of highly qualified teachers. The training of a physical education teacher should include the following blocks of subjects: professional theoretical and practical training, natural sciences, theory and methods of physical education of schoolchildren, special training in the chosen sport.

The results of discriminant analysis show that physical education teacher training is aimed at developing knowledge, abilities and skills in the sections: 1) Means and Methods of Physical Education; 2) Theory and Methods of Motor Abilities Development; 3) Theory and Methods of Teaching Motor Actions.

\section{Acknowledgement}

The study was carried out in accordance with the plan of research work of the Department of Theory and Methodology of Physical Education of H. S. Skovoroda Kharkiv National Pedagogical University.

\section{Conflict of interest}

The authors declare no conflict of interest.

\section{References}

Perez-Encinas Adriana, \& Rodriguez-Pomeda Jesus (2018). A Probabilistic Approach to Studies in Higher Education. $B$ Theory and Method in Higher Education Research (T. 4, cc. 19-30). Emerald Publishing Limited. https://doi.org/10.1108/S2056-375220180000004003

Vukasovic Martina (2019). Analysing Policy Positions of Stakeholder Organizations in Higher Education: What, How and Why? B Theory and Method in Higher Education Research (T. 5, cc. 1-17). Emerald Publishing Limited. https://doi.org/10.1108/S2056-375220190000005002

Liu Xiqian, \& Borden Victor (2019). Addressing Self-selection and Endogeneity in Higher Education Research. B Theory and Method in Higher Education Research (T. 5, cc. 129151). Emerald Publishing Limited. https://doi.org/10.1108/S2056-375220190000005009

van Vught Frans A., van der Wende Marijk C., \& Westerheijden Don F. (2018). Globalisation and Differentiation in Higher Education Systems. B Theory and Method in Higher Education Research (T. 4, cc. 85-101). Emerald Publishing Limited. https://doi.org/10.1108/S2056-375220180000004007

Muszkieta, R., Napierała, M., Cieślicka, M., Zukow, W., Kozina, Z., Iermakov, S., \& Górny, M. (2019a). The professional attitudes of teachers of physical education. Journal of Physical Education and Sport, 19, 92-99. Scopus. https://doi.org/10.7752/jpes.2019.s1014

Muszkieta, R., Napierała, M., Zukow, W., Cieślicka, M., Iermakov, S., \& Kozina, Z. (2019b). The relationships setting between evaluation actions the and styles of didactic transport at teachers of physical education. Journal of Physical Education and Sport, 19, 100-107. Scopus. https://doi.org/10.7752/jpes.2019.s1015

Popovych, I., Zavatskyi, V., Tsiuniak, O., Nosov, P., Zinchenko, S., Mateichuk, V., Zavatskyi, Y., \& Blynova, O. (2020). Research on the types of pre-game expectations in the athletes of sports games. Journal of Physical Education and Sport, 20(1), 43-52. https://doi.org/10.7752/jpes.2020.01006

Prystupa, Y., Kryshtanovych, S., Danylevych, M., Lapychak, I., Kryshtanovych, M., Sikorskyi, P., Podolyak, Z., \& Basarab, V. (2020). Features of formation the professional competence of future managers of physical culture and sports. Journal of Physical Education and Sport, 20, 441446. Scopus. https://doi.org/10.7752/jpes.2020.s1064

Richards, K. A. R., \& Levesque-Bristol, C. (2014). Student Learning and Motivation in Physical Education. Strategies, 27(2), 43-46. https://doi.org/10.1080/08924562.2014.879431

Kokun, O., Imas, Y., Vovkohon, A., Potop, V., Korobeynikov, G., Korobeynikova, L., Gorashchenco, A., \& PolevayaSecaryanu, A. (2018). Physical education and sports as a tool for formation of students' psychophysiological readiness to their professional work. Journal of Physical Education and Sport, 18(2), 966-971. Scopus. https://doi.org/10.7752/jpes.2018.02143

Kravchuk, T. (2008). Osoblyvosti provedennia navchalnoi praktyky zi sportyvnykh dystsyplin yak odniiei z form profesiinoi pidhotovky maibutnikh uchyteliv fizychnoi kultury v druhii polovyni XX st. Teoriâ ta Metodika Fizičnogo Vihovannâ, (3), 3-5.

Retrieved from https://tmfv.com.ua/journal/article/ view/401 
Kravchuk, T. (2006). Analiz navchalnykh planiv ta prohram zakladiv fizkulturnoi osvity Ukrainy za 20-30 rr. XX st.Teoriâ ta Metodika Fizičnogo Vihovannâ, (2), 9-12. Retrieved from https://tmfv.com.ua/journal/article/ view/203

Backman, E., \& Barker, D. M. (2020). Re-thinking pedagogical content knowledge for physical education teachersimplications for physical education teacher education. Physical Education and Sport Pedagogy, 25(5), 451-463. Scopus. https://doi.org/10.1080/17408989.2020.1734554

Koh, K. T., Ong, S. W., \& Camiré, M. (2016). Implementation of a values training program in physical education and sport: Perspectives from teachers, coaches, students, and athletes. Physical Education and Sport Pedagogy, 21(3), 295-312. https://doi.org/10.1080/17408989.2014.990369

Serhiienko, L. (2010). Do vprovadzhennia novoi navchalnoi dystsypliny "Terminy i poniattia u fizychnii kulturi” v navchalni plany studentiv fizkulturnykh spetsialnostei. Teoriâ ta Metodika Fizičnogo Vihovannâ, (8), 19-25. Retrieved from https://tmfv.com.ua/journal/article/ view/647

Serhiienko, L. (2009). Do problemy planuvannia vyvchennia navchalnoi dystsypliny "Metody naukovykh doslidzhen $\mathrm{u}$ fizychnii kulturi”. Teoriâ ta Metodika Fizičnogo Vihovannâ, (3), 19-26.

Retrieved from https://tmfv.com.ua/journal/article/ view/506
Khudolii, O., \& Zabora, A. (2002). Stan i shliakhy udoskonalennia vykladannia spetsialnykh dystsyplin v systemi bazovoi osvity na fakultetakh fizychnoi kultury pedahohichnykh vuziv. Teoriâ ta Metodika Fìzičnogo Vihovannâ, (3), 2-5. Retrieved from https://tmfv.com.ua/ journal/article/view/60

Khudolii, O., \& Ivashchenko, O. (2012). Problemy planuvannia vyvchennia navchalnoi dystsypliny "Teoriia ta metodyka dytiachoho i yunatskoho sportu". Teoriâ ta Metodika Fìzičnogo Vihovannâ, (10), 19-31.

Retrieved is https://tmfv.com.ua/journal/article/view/829

Khudolii, O., \& Ivashchenko, O. (2008). Problemy vykladannia dystsypliny "Teoriia i metodyka fizychnoho vykhovannia" v protsesi pidhotovky vchytelia fizychnoi kultury. Teoriâ ta Metodika Fizičnogo Vihovannâ, (2), 19-34.

Retrieved iз https://tmfv.com.ua/journal/article/view/398

Ivashchenko, O., \& Khudolii, O. (2010). Parametrychnyi pidkhid do otsinky tvorchykh robit studentiv fizkulturnykh navchalnykh zakladiv. Teoriâ ta Metodika Fìzičnogo Vihovannâ, (1), 3-6.

Retrieved from https://tmfv.com.ua/journal/article/ view/590

Roters, T. (2007). Shliakhy vdoskonalennia vykladannia teorii i metodyky fizychnoho vykhovannia u spetsializovanomu navchalnomu zakladi. Teoriâ ta Metodika Fìzičnogo Vihovannâ, (4), 16-18. Retrieved from https://tmfv.com. ua/journal/article/view/299

\title{
ДИДАКТИКА: МЕТОДОЛОГІЧНІ ПІДХОДИ ДО ВИЗНАЧЕННЯ ЗМІСТУ ПІДГОТОВКИ ВЧИТЕЛЯ ФІЗИЧНОЇ КУЛЬТУРИ
}

\author{
Ольга Іващенко ${ }^{1 A B C D}$, Радослав Мушкета ${ }^{1 A B C D}$, Владімір Потоп ${ }^{3 A B C D}$ \\ ${ }^{1}$ Харківський національний педагогічний університет імені Г. С. Сковороди \\ ${ }^{2}$ Університет Миколи Коперника \\ ${ }^{3}$ Екологічний університет Бухареста
}

Авторський вклад: А - дизайн дослідження; В - збір даних; C - статаналіз; D - підготовка рукопису; Е - збір коштів

Реферат. Статья: 6 с., 6 табл., 1 рис., 21 джерело.

Мета дослідження - розробити методологічні підходи до визначення змісту підготовки вчителя фізичної культури.

Матеріал і методи. У дослідженні взяли участь 62 студенти факультету фізичного виховання, які навчалися за навчальним планом 2001-2005 рр. Для вирішення поставлених завдань були використані як філософські, так і загальнонаукові методи дослідження, серед яких: діалектичний метод (принцип історизму, принцип системності, принцип діалектичного протиріччя, принцип єдності якості і кількості, принцип діалектичного заперечення, принцип розвитку, принцип причинності); системний підхід; факторний і дискримінантний аналіз.

Результати. Результати аналізу успішності свідчать про середній рівень володіння навчальним ма- теріалом. За величеною коефіцієнта варіації оцінки 3 «Історія сучасного світу», «Культурологія», «Гімнастика», «ТМФВ, 3 курс» мають значні коливання (>33\%). Успішність студентів з дисциплін «ЛФК», «Основи екології», «Дипломна робота» має середній рівень коливання. За більшістю показників студенти оцінюються як однорідна група. Аналіз спільностей (h2) показав, що найбільш інформативними показниками якості підготовленості студентів є оцінка 3 дисциплін: «Педагогічна практика в школі (середні класи)» (0.817); «Біомеханіка» (0.772); «Кваліфікаційний іспит» (0.764); «Педагогічна практика в школі (старші класи)» (0.763).

Висновки. Факторний і дискримінантний аналіз дозволив отримати об’єктивну інформацію про якість підготовки вчителя фізичної культури. 
Результати факторного аналізу не підтверджують об’єктивність емпіричного виділення чотирьох груп навчальних предметів навчального плану. Факторна структура навчального плану вказує на необхідність зміни змісту навчання, спрямованого на поліпшення підготовки учителя високої кваліфікації. Підготовка вчителя фізичної культури повинна включати блоки дисциплін: фахової теоретичної і практичної підготовки, природничо-наукової підготовки, теорії і методики фізичного виховання школярів, спеціальної підготовки в обраному виді спорту. Результати дискримінантного аналізу вказують на те, що підготовка вчителя фізичної культури спрямована на формування знань, умінь і навичок за розділами: 1) «Засоби і методи фізичного виховання»; 2) «Теорія і методика розвитку рухових здібностей»; 3) «Теорія і методика навчання рухових дій».

Keywords: вчитель фізичної культури, зміст підготовки, факторний аналіз, дискримінантний аналіз.

\section{Information about the authors:}

Ivashchenko Olha: o.ivashchenko@yahoo.com; https://orcid.org/0000-0002-2708-5636; Department of Theory and Methodology of Physical Education, H. S. Skovoroda Kharkiv National Pedagogical University, Alchevskykh St, 29, Kharkiv, 61002, Ukraine.

Muszkieta Radosław: muszkieta@umk.pl; https://orcid.org/0000-0001-6057-1583; Faculty of Earth Sciences, Nicolaus Copernicus University, Jurija Gagarina St,11, 87-100 Toruń, Poland.

Potop Vladimir: vladimir_potop@yahoo.com; https://orcid.org/0000-0001-8571-2469; Dean of the Faculty of Physical education and sport, Ecological University of Bucharest, Bd.Vasile Milea nr. 1G, Sector 6, 061341 Bucuresti, Romania.

Cite this article as: Ivashchenko, O., Muszkieta, R., \& Potop, V. (2020). Didactics: Methodological Approaches to Determining the Content of Physical Education Teacher Training. Journal of Learning Theory and Methodology, 1(1), 40-47 https://doi.org/10.17309/jltm.2020.1.06

Received: 27.05.2020. Accepted: 20.06.2020. Published: 30.06 .2020

This work is licensed under a Creative Commons Attribution 4.0 International License

(http://creativecommons.org/licenses/by/4.0). 